\title{
Kan brugen af mobiletelefoner i undervisningen styrke elev-centrerede læreprocesser?
}

\section{Judith Seipold}

Ph.d.-studerende

Medienpädagogik, Universität Kassel og medlem af London Mobile Learning Group (LMLG)

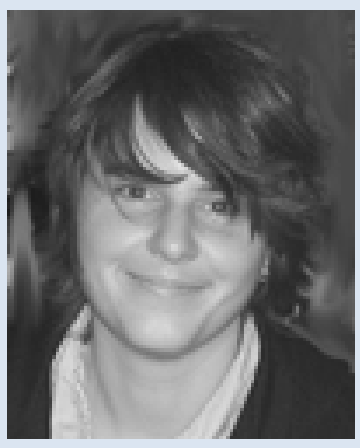




\section{Indledning}

Mobil læring er et emne på vej frem. Det er ikke kun det konstant tiltagende antal af konferencer om m-læring, der understøtter dette faktum (Traxler 2007). Overgangen fra at betragte fordelene og ulemperne ved mlæring i praksis til dannelse af teorier karakteriserer også, hvordan denne disciplin er ved at blive voksen. Sidst men ikke mindst implementeres i stigende grad projekter med mobiltelefoner og med relevans for læring, som bliver realiseret inden for og uden for skolen, i job- og fritidssammenhænge. Sådanne projekter stræber mod at forbedre læring og undervisning, læse-, skrive- og læringskompetencer for at støtte fremmøde, adfærd og sociale færdigheder, og for at imødegå den digitale kløft, social udelukkelse osv. - helt generelt: "Research into mobile learning is the study of how the mobility of learners augmented by personal and public technology can contribute to the process of gaining new knowledge, skills and experience" (Sharples et al. 2007). Målene i forbindelse med forskning er lige så forskellige som måderne, hvorpå m-læring implementeres - de funktioner, der bliver anvendt på mobiletelefonerne, er lige så omfattende som elevernes aktiviteter.

Den pædagogiske dimension bag målet om at opnå kontinuerlig læring med fokus på elevernes erfaringer, kulturelle praksisser, viden osv. fra hverdagen opstår på baggrund af mindst to dimensioner: En af disse er behovet for livslang læring der har en uddannelsespolitisk dimension (se f.eks. COMM/EAC 2008). Livslang læring tager ikke kun formel og ikkeformel læring i betragtning, men også uformel læring, der refererer til områder og aktiviteter som ikke direkte er at finde i uddannelsesmæssige sammenhænge men hovedsagligt i elevens hverdag. Denne tilgang fastholder perspektivet om integration af uformel læring i sin bredeste forstand i skolesystemet, men med et behov for at moderere denne uformelle læring og for at gøre eleverne opmærksomme på, hvordan de produktivt kan bruge deres mønstre i deres læring. En anden dimension refererer til skolen som et sted, hvor der er plads til uformelle aktivitetsmønstre og handlingsorienteret mediebrug i specifikke situationer f.eks. i forbindelse med projektforløb. I den resterende tid dominerer skolens regler, og aktiviteter der normalt foregår uden for skolen kan måske medføre regler og begrænsninger, som kan være prekære for eleverne, hvilket Herbert Schweizer (2007) skitserer. Men i stedet for at udvikle sådanne kløfter er det skolens opgave at støtte eleverne i deres meningsdannelse og læring, selvom det er nødvendigt at moderere forholdet mellem skolens og hverdagens perspektiver samt at sætte information og viden ind i den rette sammenhæng. Alligevel bliver denne opgave realiseret ret tøvende. 
I denne artikel bliver spørgsmålet om kontinuitet inden for læring sat i forbindelse med at skabe relationer mellem elevens kulturelle praksisser og uformelle læring uden for skolen og læring med mobile medier inden for skolens rammer. Som det vil vise sig, bliver mobiltelefoner brugt som redskaber i skoler, men deres "originale" formål, der stammer fra elevernes daglige brug af mobile medier, bliver sjældent taget i betragtning. Det lader til, at dette afhænger af lærerens didaktiske design; jo mere undervisningen er rettet imod at eleverne selv er organiserede og ansvarlige for deres læring, des mere synes brugen at fokusere på de mobile mediers situerede betydning og deres respektive egenskaber. Derfor bliver mobiltelefonen nogle gange brugt mere formelt som et redskab inden for læring, og nogle gange bruges den under forholdsvis uformelle vilkår og i overensstemmelse med situerede krav og elevens kulturelle praksisser. Personlig, kommunikativ og samarbejdsmæssig læring såvel som elevernes viden/praksisser bliver derfor fremhævet.

\section{Mobiltelefoners potentiale for læring - mod elevcentreret og selvreguleret læring}

Når det drejer sig om at forbedre læring og undervisning, beskrives mobil læring som "spontaneous, personal, informal, contextual, portable, ubiquitous (available everywhere) and pervasive (so integrated with daily activities that it is hardly noticed)" (Kukulska-Hulme 2005, s. 2). "Mobile learning can be [...] situated; it can be [...] unobtrusive [...] and disruptive" (Kukulska-Hulme \& Traxler 2005, s. 42), and "ambient" too (KukulskaHulme 2005, s. 2). Det medfører "advantages and drawbacks of more varied and changing locations, more immediate ('anytime') interaction, and smaller, often wireless devices" (Kukulska-Hulme 2005, s. 2). Disse egenskaber refererer til mobile apparaters teknologiske karakteristika, men de markerer også et skift i retningen mod forskellige områder, hvor læring finder sted samt mod et perspektiv, der betragter eleven som det centrale i undervisning, læring og videnskonstruktion. Med mobil læring, der er beskrevet som "highly situated, personal, collaborative and long term; in other words, truly learner-centred learning" (Naismith et al. 2004), får samarbejdsmæssig, personaliseret og elevcentreret læring mere og mere opmærksomhed.

\footnotetext{
"Mobile technologies offer learning experiences which can effectively engage and educate contemporary learners and which are often markedly different from those afforded by conventional desktop computers. These devices are used dynamically, in many different settings, giving access to a broad range of uses and situated learning activities. The personal nature of these technologies means that they are well suited to engaging learners
} 
in individualised learning experiences, and to giving them increased ownership (and hence responsibility) over their own work."

(Naismith et al. 2004, s. 7)

Forandringen i at opfatte læring som en kommunikativ, interaktiv og meningsfuld aktivitet inden for videnskonstruktion (se Laurillard 2002, 2007) snarere end en passiv og modtagende aktivitet - fra undervisning til læring (Kukulska-Hulme \& Traxler 2005, s. 25) - er med til at forandre lærerens og elevens roller. Lærerne betragtes som leverandører af information og som moderatorer, der giver råd, vejledning og støtte til eleverne om, hvordan man organiserer læring (Kukulska-Hulme \& Traxler 2005) snarere end som "transmitters of knowledge" (Naismith et al. 2004, s. 36). Hvad angår eleverne, som denne artikel fokuserer på, kan dette nyvundne ansvar føre til muligheder såvel som risici: Mulighederne kan referere til integrationen af elevernes handlen, deres individuelle erfaringer, interesser, kvalifikationer, evner, viden osv. i processen med at konstruere viden. Risikoen er, at man kan være ude af stand til at klare denne proces - og at man selv er ansvarlig for sin egen fiasko.

\section{Hinsides teknologi - overvejelser af elevernes handlen i skolesammenhænge}

Som den tyske sociologiprofessor Herman Schweizer (2007, s. 435) pointerer, opstår der visse risici, hvis handlings- og aktivitetsmønstre, som foregår uden for skolen, integreres med deciderede skolestrukturer. Spontan aktivitet og samvirke (uformel og hverdagsrelateret), som opstår i ustrukturerede og kommunikative tilegnelsesprocesser er ikke fuldstændigt udelukkede fra formelle organisationer og institutioner. Imidlertid bliver de nødt til at bevæge sig væk fra uformelle sammenhænge, hvis forhold til det formelle niveau er prekært. Konsekvensen bliver en tilsyneladende formalisering af uformelle aktiviteter og perspektiver, der har nichekarakter, og som altid vil forblive i afstand til og være i modstrid med den "store scene", det formelle niveau (Schweizer 2007, s. 435). På dette tidspunkt - som markerer et brud mellem hverdagslivet og skolen - bliver behovet for diskursiv og kommunikativ moderation relevant. Det vil være lærerens opgave at indskrænke risici for elever ved at fungere som moderator samt at stille rammer og rum til rådighed, hvori elever i forbindelse med læring kan handle succesfuldt og i dette perspektiv vende tilbage til diskursiv og kommunikativ meningsdannelse, til deres erfaringer, præferencer og strategier i forbindelse med håndtering af information og konstruktion af viden. 
Bachmair et al. (2009) hævder i deres artikel

(http://forskningsnettet.dk/sites/default/files/file/LOM/lom5.2010/7 Mo

biltelefoner som kultur pdf.pdf) , at skolen har mulighed for at betragte elevers kulturelle praksisser - i bredere forståelse deres handlemåder, aktiviteter og viden fra hverdagen - i forbindelse med skoleundervisning og læring samt i forbindelse med kulturelle ressourcer såsom mobiltelefonen. De læner sig op ad de strukturelle aspekter ved Piagets termer "akkommodation" og "assimilation" for at kunne beskrive læreres og elevers faktiske og potentielle "reaktioner" på mobiltelefonen, der anses som en reel del af hverdagen og massekommunikation. Man kan forestille sig "an assimilative or accommodative adjustment of cultural practices of meaning making in the modus of learning" (Bachmair 2008) i stedet for at udnytte dem til modernisering af skoler eller til teknologisk fornyelse i

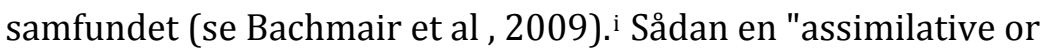
accommodative adjustment", der har som mål at tilvejebringe kontinuitet inden for læring på tværs af kontekster og "seamless transitions within and across dimensions of mobility" (Arnedillo-Sánchez 2008, s. 77) kan opnås ved at vende tilbage til strukturer, som er opnået igennem handlen og meningsfuld brug af medier i forskellige situationer i hverdagen samt i skolen: elevernes foretrukne medier, anvendelsesmuligheder og teknologi, deres mønstre for brug, deres interesser, deres viden osvii. I denne sammenhæng menes det teknologiske aspekt at støtte kulturelle praksisser, og mobil læring bliver betragtet som kommunikativt og samarbejdsmæssigt samspil (Pachler 2008). Dette viser, at mobiltelefoner er redskaber til situeret meningsdannelse snarere end medier, som transporterer indhold og forudbestemte betydninger.

\section{"Brugergenerede" kontekster - forbindelsen mellem uformel hverdagslæring og formel}

\section{skolelæring}

Eftersom teknologien betragtes som anvendelig til at skabe kontinuerlig læring ved at understøtte, at læring kan ske når som helst og hvor som helst - i fysisk, begrebsmæssig, socialt rum, "dispersed in time" (Sharples et al. 2007) - men som først og fremmest betragtes som et redskab til at understøtte kulturelle praksisser, er det måske værd at kigge på, hvordan mobiltelefoner bliver brugt i forskellige sammenhænge dvs. i hverdagen og i skole. Samtidig skal vi huske på, at kontinuerlig læring ikke kun skal sættes i forbindelse med dimensioner såsom tid og rum, men også med de involverede menneskers kulturelle praksisser. Til at begynde med og for at introducere dynamiske, "forhandlede" og situerede begreber om brugen af mobiltelefoner introduceres definitioner af kontekstiii, som er afgørende inden for forskning om mobil læring, og som tilvejebringer brugbare 
begreber til et analytisk grundlag ved ikke blot at referere til kendsgerninger men også til dynamiske processer.

"Mobile learning is not just about learning using portable devices, but learning across contexts"

(Walker 2006, s. 2).

Når det kommer til definitionen af "kontekst", eksisterer der forskellige opfattelser, der betragter kontekst som enten stabil og forudsigelig eller som udviklende og dynamisk - eller som en kombination af de to (se Dourish 2004 for en detaljeret oversigt). Ifølge Luckin et al. (2005) kan kontekst være både stabil og dynamisk. De stabile elementer er relevante, når det kommer til kategorisering af ressourcer, mens det dynamiske begreb er relevant i forhold til at forstå elevernes handlemåder og aktiviteter:

"[...] a set of inter-related resource elements, the interactions between which provide a particular context. In keeping with our previous discussions, both here and in Luckin (2005), this definition has both a static dimension, through which the resources can be identified and categorized, and a dynamic dimension that describes the organizing activities that activate the resources and form an Ecology that is centred on the learner. The categories in the static dimension are: what is to be learnt (Content), how it is to be learnt (Process) and where it is to be learnt (Place.)"

Med reference til Bakardjieva ("technology-in-use-in-social-situations"; Bakardjieva 2005, s. 34) fokuserer Cook et al. på den dynamiske dimension dvs. elevers handlen og meningsfulde aktiviteter med mobile enheder i bestemte sociale situationer (Cook et al. 2007).

\footnotetext{
"[...] technology extended to include the acts of use in social situations. This is where a user enacts or invents 'use genres', i.e. they mobilise available cultural tools to respond to a social situation."

(Bakardjieva 2005, s. 34; citeret fra Cook et al. 2007)
}

I den forstand er den hensigtsmæssige brug af redskaber i bestemte situationer basis for konstruktionen af kontekster.

"Provisionally, we define a 'mobile learner generated context' as being conducted by a learner or learners who: 


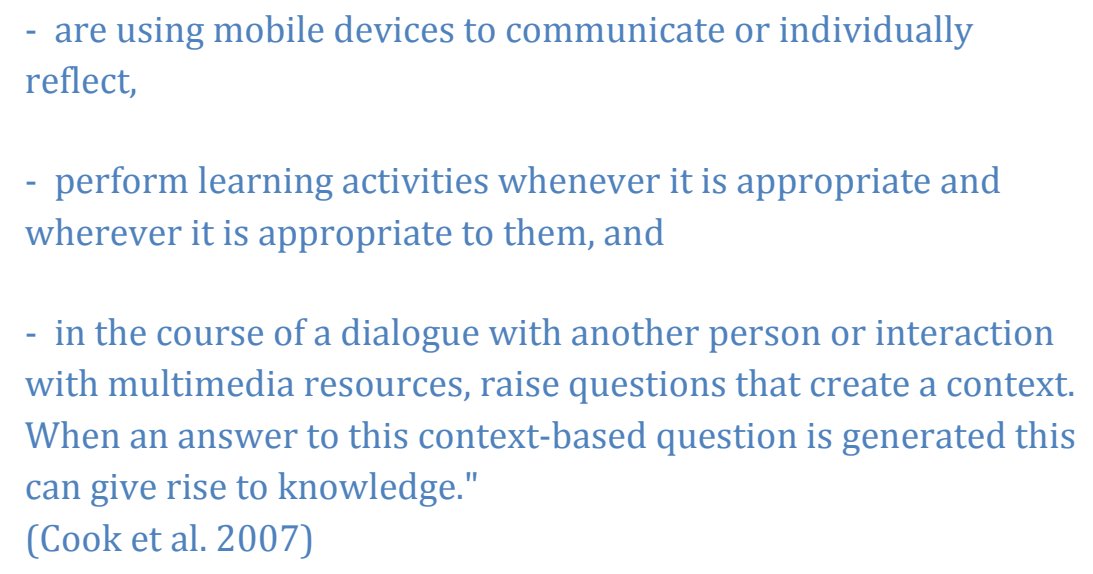

I forbindelse med spørgsmålet om at skabe kontinuerlig læring kan en dynamisk forståelse af kontekst måske ses som en hindring i forsøget på at opnå stabilitet og kontinuerlig læring imellem og på tværs af kontekster. Imidlertid bærer diskussionen om mobil læring i skoler med henblik på kontinuerlig læring vidnesbyrd om behovet for at forstå kontekst som delvist stabilt og forudsigeligt og delvist som dynamisk og frembragt af eleven. De kulturelle ressourcer dvs. mobiltelefonerne som stabile kontekster kan skabe kontinuitet i forbindelse med sted, tid, teknologiske relationer, indhold osv. Aktiviteterne som dynamiske dimensioner betragtes som forbindelser mellem hverdagen og skolen ved at referere til strukturer inden for den dynamiske proces, som begge "sfærer" (skolen og hverdagen) har til fælles, som er til stede i elevernes kulturelle praksisser inden for og uden for skolen, og som tillader stabile rammer samt muligheden for at blive forhandlet afhængig af situationen og i socialt samspil. Sådanne strukturer kan f.eks. være regler. I de følgende afsnit forklares elevernes nære forhold til regler i skolen ved hjælp af eksempler fra ikt (informations- og kommunikationsteknologi). Der gives tre eksempler, som sigter efter at vise, at der - inden for mobil læring i skoler eksisterer regler, der hersker enighed om eller er klarlagt i forvejen og håndteres som stabile såvel som regler om dynamiske og åbne omgivelser, der fremkalder en situationsbunden, forhandlingsmæssig og aktivitetsorienteret brug af mobiltelefoner i skolen.

\section{"Elevens stemme" - regler og forskrifter: forhindringer eller udfordringer?}

Et projekt om børns brug af ikt i klasselokalet og i deres fritid fra London Knowledge Lab på Institute of Education, University of London (Cranmer et al. 2008) gav et interessant indblik i elevernes forståelse af læring med ikt i forskellige kontekster. Elevernes opfattelser af mulighederne (Kress og Van Leeuwen 1996, 2006) ved brug af ikt inden for og uden for skolen var 
meget tydelig ligesom deres vilje til at møde bestemte strukturer ved hjælp af regler og forskrifter, når de foreslog medier, der anvendes uden for skolen, skulle integreres i skolen med det formål, at

(a) eleverne finder læring med ikt (i dette tilfælde ved at referere til spil) inden for skolens rammer seriøst, mens læring i deres brug af ikt uden for skolen og i deres fritid betragtes som sjov og leg. Imidlertid er det næppe sandsynligt, at elever ser muligheden for at bringe disse to sfærer sammen.

"Boy Like on the computer when you're sometimes playing games you could do mathematical games or science questions and stuff like that so you can learn more when you come to school you know a little bit more about the subject.

Int. So do you think that maybe there should be more games in school on the school computers?

Boy Yeah.

Boy I don't think so because it might interfere with real learning.

Int. So games is not real learning?

Boy Well sometimes it is but other times it ain't." (Cranmer et al. 2008, s. 23)

(b) Eleverne forbinder brugen af ikt, som de kender uden for skolen, med regler og forskrifter inde i klasselokalet. Anvendelsen af deres foretrukne medier inden for skolens rammer - hvilket mange elever mener er med til at gøre læringen sjovere (Cranmer et al. 2008, s. 28) - bliver begrænset af dem selv, fordi de kun tillader den regulerede brug i bestemte tidsperioder og situationer, hvorimod læreren i den resterende tid skal opbevare apparaterne, sådan at eleverne ikke leger med dem i løbet af timerne. Sådanne forslag er måske relateret til de sociale ønsker i skolesammenhænge, og elevernes oplevelse af skolen som et kulturelt defineret rum med dets egne regler og forskrifter - hvilket inkluderer regulering af accept og brug af medier fra fritiden inden for skolens rammer.

\footnotetext{
"It was notable that many of these suggestions for change adopted an almost pleading tone and were often qualified by an acknowledgement and (begrudging) acceptance of school restrictions and regulations. This was evident, for example, in the labels that children attached to their pictures outlining a range of conditions to their visions for future change, e.g. "games at playtime instead of going outside at playtime" [male, yr. 5, \#269], "iPod then you give it to the teacher and she looks after it till spesail time [sic]" [female, yr. 6, \#548], "play games if the whole class has had a stressful day" [female, yr. 6, \#212] and "ten minutes of time on the computer to do whatever we want as long as its safe" [female, yr. 5, \#269] (see also figure eleven's provisos
} 
for use 'if good', 'if you are star of the week', and only during

'freetime')."

(Cranmer et al. 2008, s. 30f)

På den anden side har elever måske erfaret, at regler og forskrifter ikke kun inkluderer begrænsninger, men måske snarere skaber forhandlede rum med relativ frihed og råderum i forbindelse med deres handlen, kulturelle praksisser og kulturelle ressourcer (Seipold 2005). Imidlertid kan elevernes fokus på spil ("gaming") og deres viden om regler og forskrifter måske skabe en forbindelse mellem lege-aktiviteter uden for skolen og afpasset læring i skolen. Både i lege-aktiviteter og i skolen skaber regler basis for kulturelle praksisser. Som Brynskov (2007) skitserer, kan lege-aktiviteter beskrives som "unstructured (ludic activity), over somewhat structured (play) to highly structured (game)" (Brynskov 2007, s. 9). Men snarere end at betragte disse forskellige slags lege-aktiviteter som stabile, refererer han til "transformative social play" (ibid.) som en dynamisk og ustruktureret proces, hvori regler bliver forhandlet i social interaktion.

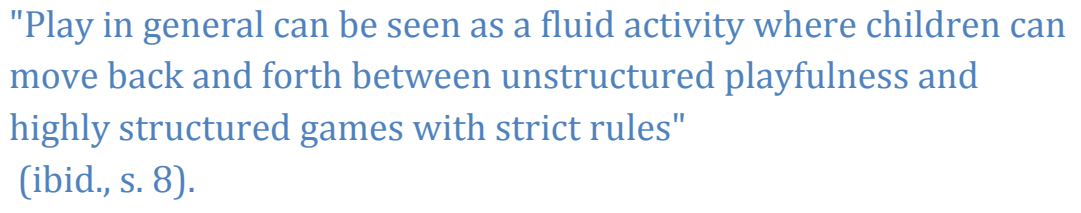

Regler i disse to eksempler, de danske og de engelske, bliver betragtet som essentielle i implementeringen og brugen af teknologi i skolesammenhænge. Desuden er det måske indlysende, at regler enten forhandles eller klarlægges på forhånd, eller at de bliver forhandlet dynamisk og ændret, når de kommer i brug. Regler i form af strukturer, der fungerer som orienteringsmønstre i skolen såvel som uden for skolen, bliver betragtet som forbindelsesled mellem hverdagslivet og skolen. For at få en forståelse af en eventuel reguleret eller dynamisk brug af mobiltelefoner er to spørgsmål centrale i de videre betragtninger: (1) Hvor er der forskelle i brugen af mobiltelefoner i forskellige kontekster - i skolen og udenfor? Og (2) på hvilket tidspunkt forvandles kontinuitet i brugen af mobiltelefoner til afbrydelser, dvs. hvor foregår der en dynamisk og "forhandlende" brug af mobiltelefoner i skoler? 


\section{Mobiltelefoner og internettet i unge}

\section{menneskers hverdag (iv) - redskaber til brug i kommunikation, deltagelse og forhandling}

Relevansen af mobiltelefoner i unge menneskers liv, de sociale implementeringer af brugen af den slags teknologi og indvirkningen på identitetsdannelse, fællesskabsdannelse, privatliv osv. har været et forskningsområde inden for sociologien i nogle år allerede (se f.eks. Ling 2008; Stald 2007; Glotz 2005). I stedet for at henvise til dette område fokuserer det følgende afsnit på data, som indeholder udtalelser om unges brug af mobiltelefoner, og som har relevans for skabelsen af en forbindelse mellem deres hverdagsaktiviteter og skolelæring.v

Mobile medier har ligget på de unges top 10 over foretrukne medier $\mathrm{i}$ nogle år efterhånden. Specielt mobiltelefonen spiller en stor rolle. I Tyskland i år 2008 ejede 96 \% af kvinderne og 94 \% af mændene imellem 12 og 19 år mindst én mobiltelefon. Intet andet medie er ejet af så mange som dette apparat (figur 1), og kun fjernsynet og computeren bliver anvendt oftere i fritiden (figur 2). De foretrukne mærker er Nokia, Siemens, Sony Ericsson, Motorola og Samsung (Bauer Media 2005, s. 16). De unge bruger både mobiltelefonen til underholdning (som mp3-afspiller eller til at spille spil på) og til regulering af følelser/samspil med andre (kontakt til venner, udtrykke følelser via SMS). Også "inspiration" i forbindelse med at bruge mobiltelefonen som en genstand, der signalerer stil eller prestige eller som en platform til at bytte musik, videoer og billeder er vigtige anliggender for de unge (Bauer Media 2007, s. 46). 


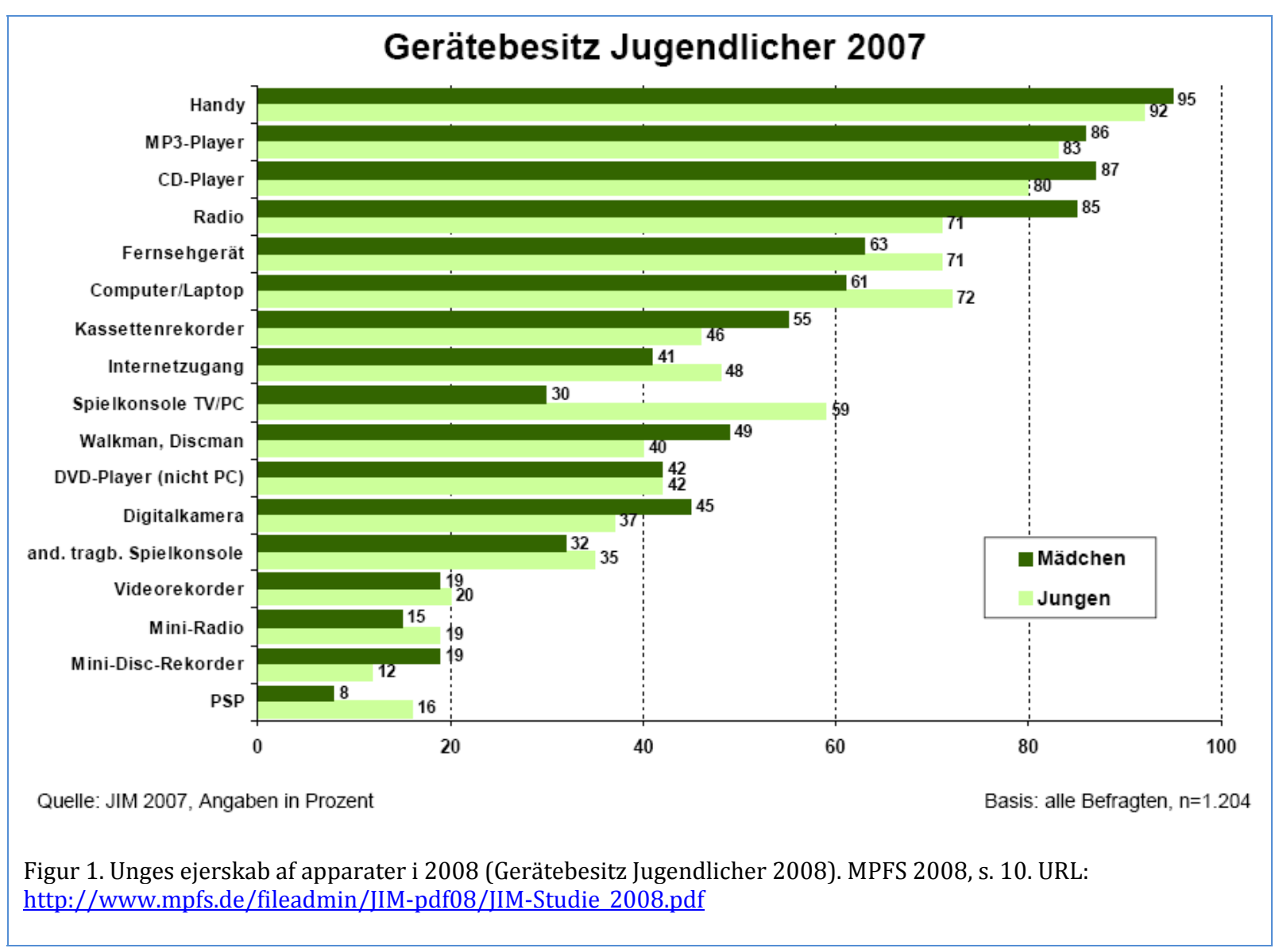




\section{Medienbeschäftigung in der Freizeit 2007 - täglich/mehrmals pro Woche -}

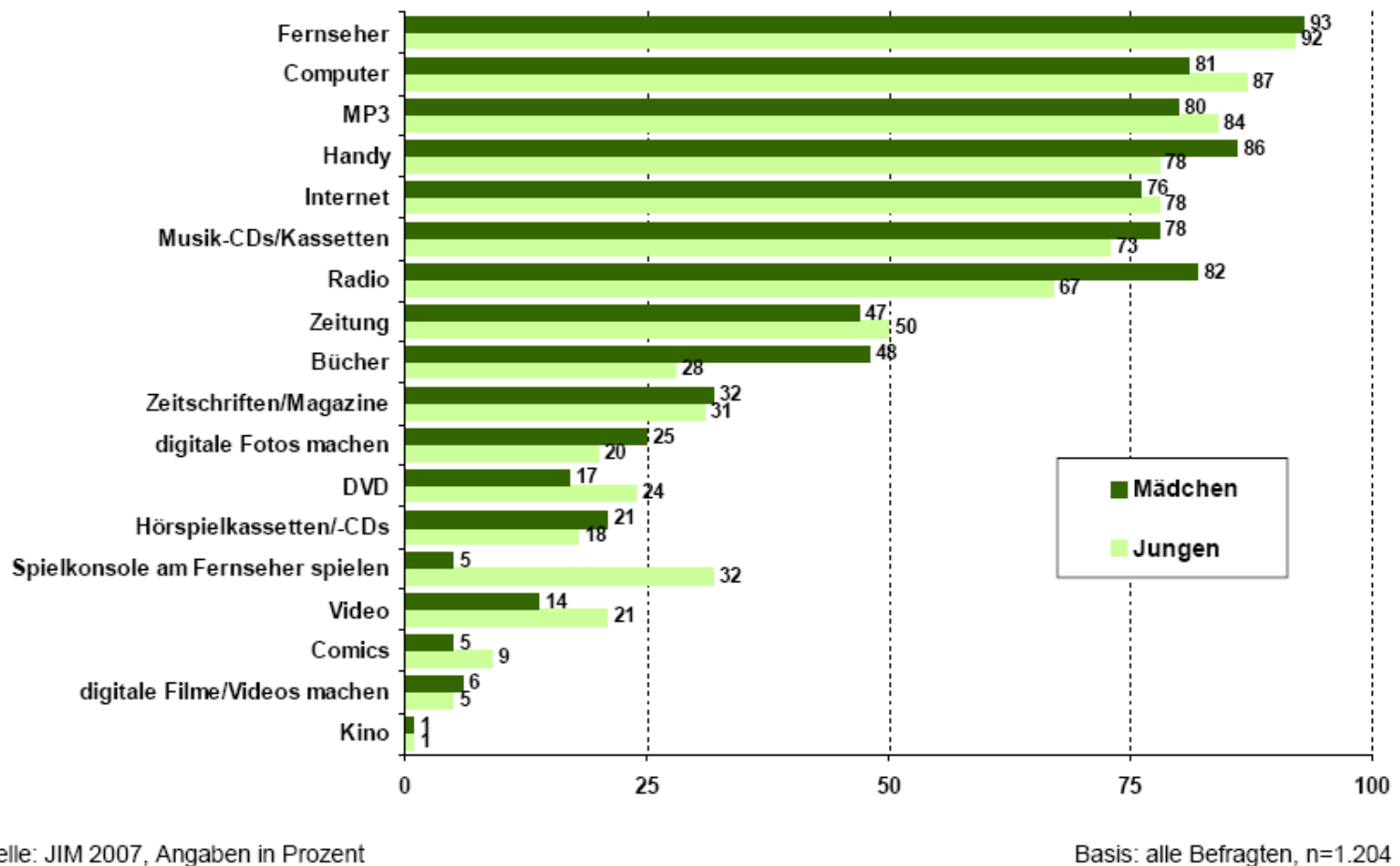

Figur 1. Beskæftigelse med medier i fritiden i 2008 (Medienbeschäftigung in der Freizeit 2008). MPFS 2008, s. 12. URL: $\underline{\text { http://www.mpfs.de/fileadmin/IIM-pdf08/IIM-Studie 2008.pdf }}$

Mobiltelefoner - redskaber til brug i kommunikation, produktion og distribution

Ifølge de data, der er angivet i figur 3 herunder, bruger unge mennesker mellem 12 og 19 år mobiltelefoner til kommunikation, underholdning, organisering og arkivering:

- Skriftlig kommunikation: SMS (sende Sms'er); e-mail

- Mundtlig kommunikation: telefon

- Underholdning: lytte til musik, spille, lytte til radio, se tv på mobilen

- Underholdningsproduktion og -dokumentation: tage billeder, optage videoer

- Informationssøgning: nyhedserhvervelse, surfe på nettet

- Arkiv/database: udveksle data via bluetooth og MMS (fotos, film, musik) 


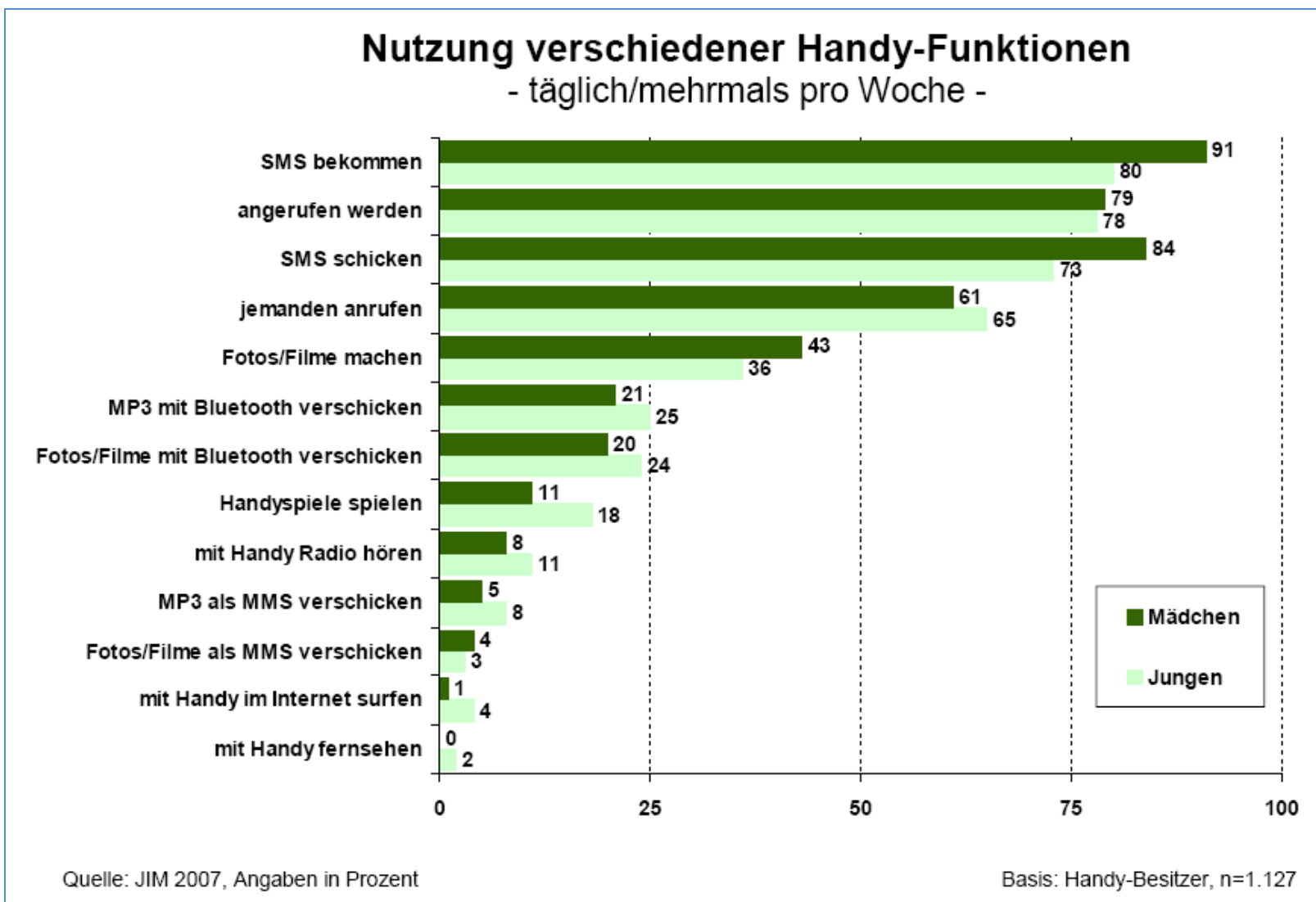

Figur 3. Brugen af mobiltelefonens forskellige funktioner (Nutzung verschiedener Handy-Funktionen). MPFS 2008, s. 63. URL: http://www.mpfs.de/fileadmin/JIM-pdf08/JIM-Studie 2008.pdf

Når man ser nærmere på kategoriseringen af mobiltelefonens forskellige funktioner, kan de følgende konsekvenser opstilles, når det drejer sig om håndtering af information eller forskellige kommunikationsformer:

- kommunikation foregår via synkron mundtlig

kommunikation samt via asynkron skriftlig

kommunikation. Synkron skriftlig kommunikation som

f.eks. chat bliver ikke nævnt.

- Som underholdningsmedie bliver audio og audiovisuelle medier, musik og spil såvel som mobil-tv anvendt; det at se film eller videoer bliver på den anden side ikke nævnt. Produktionen af underholdnings- eller dokumentarformater henviser imidlertid til produktion af de visuelt dominerede billeder og videoer snarere end til lydoptagelse eller -produktion.

- Dataudveksling relaterer sig til distribution af indhold og sandsynligvis til arkivering. Mobiltelefonen kan derfor måske bruges til (overgangs) datalagring. 
- Organisationsdimensionen, som dukkede op i 2007 med forbindelse til tidsdimensionen, bliver ikke længere nævnt i år 2008.

Kommunikation er lige så vigtigt for de 12-19-årige, som underholdning er. Up- og download af data og P2P praktiseres via kommunikation, underholdning og informationssøgning.

Internettet - et rum med plads til kommunikation, informationssøgning og underholdning

Eksemplerne på praksisser inden for m-læring, som er beskrevet herunder, inkluderer også brugen af konvergerende medier som f.eks.

internetplatforme eller weblogs. Denne teknologiske konvergens, der synes både at være central og have en vigtig symbiotisk funktion i området for mlæringspraksisser, fører til spørgsmålet om de 12-19-åriges internetaktiviteter i hverdagen. Som med brugen af mobiltelefoner er kommunikation, underholdning og arkivering centrale i unge menneskers internetaktiviteter. Desuden er informationssøgning og produktion (deltagelse) samt handel også en del af de 12-19-åriges brugsmønstre:

- Skriftlig kommunikation: chat-funktioner (instant messaging); e-mail, chat.

- Mundtlig kommunikation: tale via IP-telefoni.

- Underholdning: lytte til musik og lyd, se film og videoer, web TV, spille, lytte til webradio.

- Underholdningsproduktion og -dokumentation: podcasting.

- Informationssøgning: generel information (ikke til skolebrug); nyheder; information til skole- og jobbrug; nyhedsgrupper, regionale begivenheder, live sportstickers, læse weblogs, anvende søgemaskiner og Wikipedia.

- Informationsproduktion: skrive i nyhedsgrupper og weblogs.

- Social networking: online fællesskaber.

- Handel: at købe online

- Arkiv/database: musik, download af film og videoer; upload af videoer og billeder; upload af musik/lyd. 


\section{Internet-Aktivitäten 2007 \\ - täglich/mehrmals pro Woche -}

Instant Messaging (z.B. ICQ)
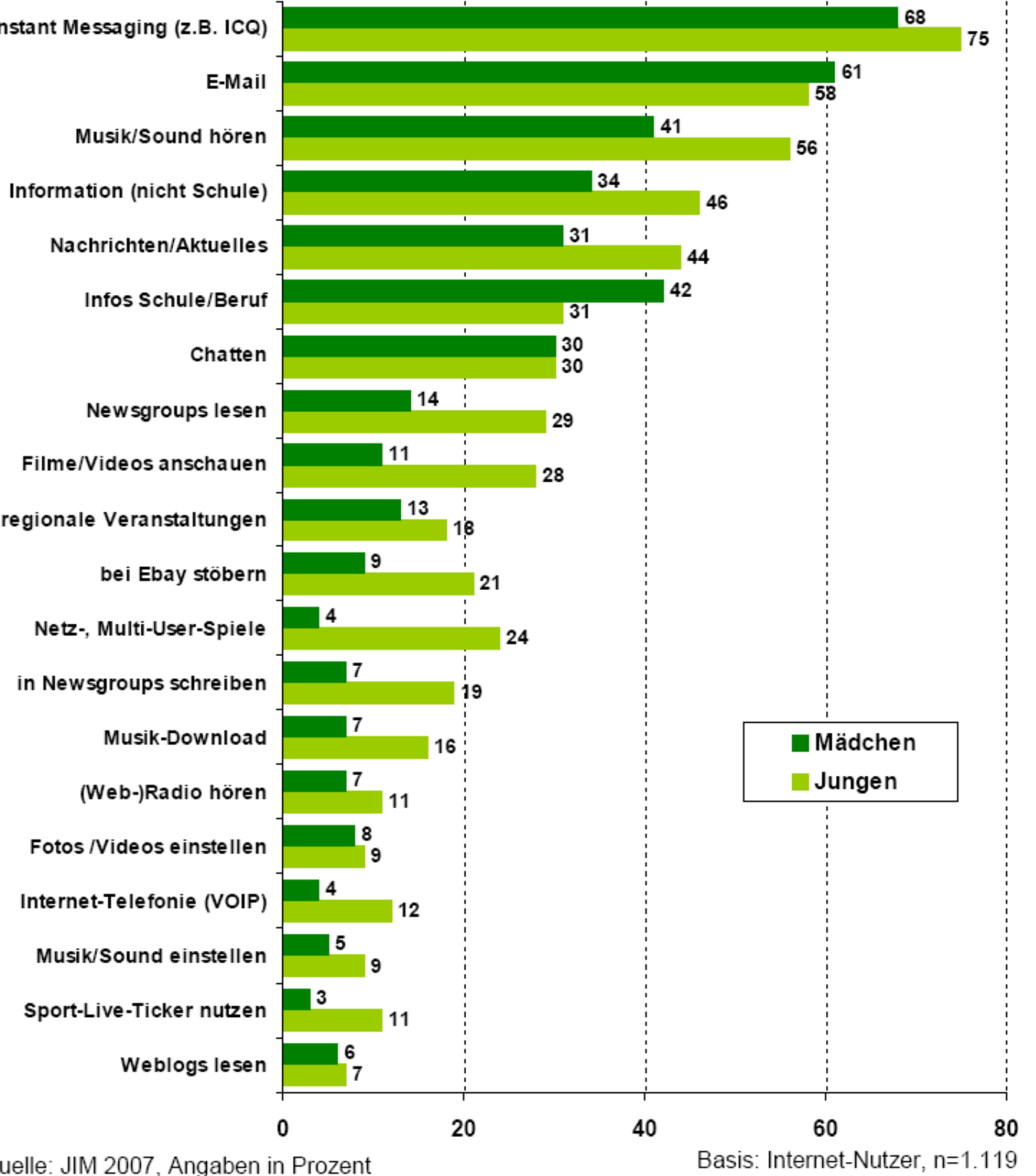

Quelle: JIM 2007, Angaben in Prozent

Basis: Internet-Nutzer, $n=1.119$ (Nennungen ab $5 \%$ ) 
Baseret på disse data kan følgende konsekvenser opstilles for håndtering af information eller kommunikation ved brugen af forskellige funktioner og kommunikationsformer:

- Kommunikation er skriftlig ved brug af forskellige formater. Synkrone og asynkrone redskaber anvendes, såvel som formater, hvori der enten indgår kort længde eller specificeret sprog (som f.eks. chatsprog) eller det mere formelle brev. Mundtlig kommunikation svarende til telefonsamtale bliver ikke anvendt særligt ofte.

- Underholdning omfatter at lytte til musik, lyd og webradio og at se film, videoer og web-tv samt at spille. Unge mennesker er modtagerne/forbrugerne af disse formater, og de er sjældent leverandører af f.eks. podcasts.

- Unge mennesker søger efter snarere end at producere information; information tilgås enten via hjemmesider, søgemaskiner, Wikipedia eller modtages via nyhedstickers og nyhedsgrupper; kun få unge bidrager til nyhedsgrupper og weblogs.

- Handel vedrører køb på internettet.

- Download af musik, film og video sker antageligvis med det formål at opbevare musik, at opbygge et depot, en database eller et arkiv.

- Social networking praktiseres af mere end $50 \%$ af de 1219-årige. Angående brugen af internet synes kommunikation, deltagelse og forhandling at være centrale aktiviteter for de 12-19-årige - ved siden af aktiviteter der kan karakteriseres som underholdning. 


\section{Eksempler på mobil læring i skoler - nye funktioner og muligheder}

Eftersom de 12-19-årige anvender mobiltelefoner og internettet på vidt forskellige måder, er spørgsmålet, om de også anvendes på samme måde i skolen, eller om der er forskelle. Ved første øjekast kan de følgende resultater opstilles: De funktioner på mobiltelefonen, som har med kommunikation, forhandling og deltagelse at gøre (telefonering, sms, social networking), bliver sammenlignet med andre funktioner der oftest bruges i hverdagen. I skolen og i forbindelse med mobil læring forsvinder kommunikationsfunktionen ofte. Dette gælder for både mundtlig og skriftlig kommunikation. Derudover står redskaber til dataindsamling og distribution i forgrunden nemlig kameraet (til at tage billeder med og optage videoer) samt funktioner, som muliggør opkobling til distribution af indhold. Det konvergerende medie er platformen/webloggen, som bliver brugt til at opbevare og arkivere information og materiale til dokumentation eller til senere genkaldelse.

De følgende eksempler baserer sig på forskellige didaktiskevi begreber. De sigter på at vise, hvordan brugen af mobiltelefoner inden for læring i skoler inkluderer alt fra transport af information til situeret brug og i forlængelse heraf bestemte muligheder, inklusiv praksisser fra hverdagen.

\section{Projekt "momo - The mobile moodle experience: MobileClassRoom"vii}

The mobile moodle experienceviii er en del af et m-læringsprojekt, der blev realiseret i faget fysik i en østrigsk Hauptschule. Elever fra 4. klasse (ottende år, 14 år gamle) deltog i dette projekt i sommersemestret 2007. Målet med denne del af projektet var at teste, om den teknologi, der bliver brugt til mobil-støttet læring, virker ordentligt; dvs. at evaluere opkobling og upload mellem mobiltelefoner og en moodle-platform. De 11 mobile apparater (Nokia N71), der blev benyttet af eleverne, var udlånt af Nokia for en begrænset periode. De skulle leveres tilbage, når projektet sluttede.

Moodle-platformen og Java-software, der blev installeret på mobiltelefonerne, gav eleverne mulighed for øjeblikkeligt at uploade deres data fra deres fysik-eksperimenter - billeder, videoer, sms'er - hvilket uden omkostninger kunne overføres til platformen. Læreren lagde elementære data og opgaver ud på moodle-platformen i forvejen. Den ekstra didaktiske værdi lå i at give eleverne en platform, hvorpå de kunne opbevare deres observationer og dermed have små men komplekse eksperimenter til rådighed på længere sigt for dermed at overkomme flygtighed og gøre materialet tilgængeligt til analyse og refleksion. Derfor 
var eleverne i stand til at referere til og tilgå deres optagelser og resultater igen for videre diskussion og beskrivelse (Schittelkopf \& nischiTV 2007).

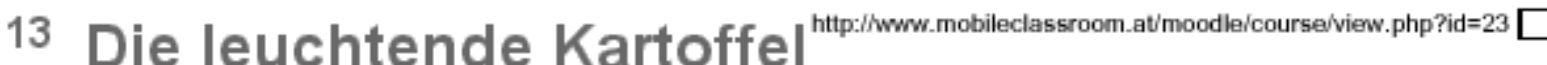

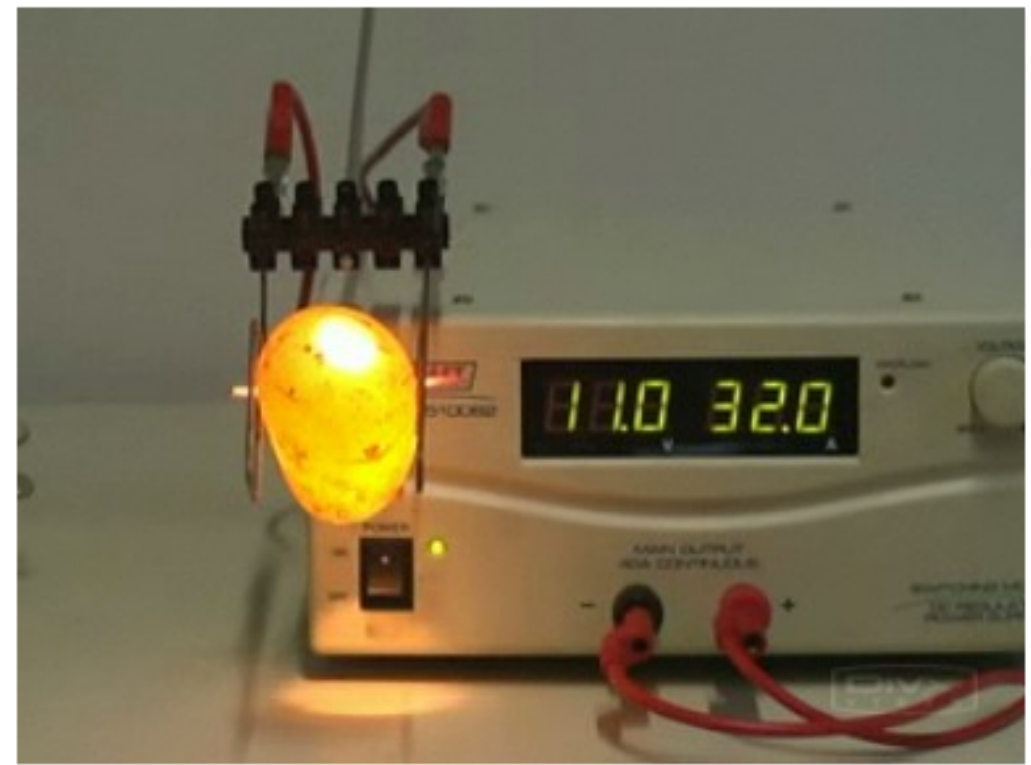

Bei diesem Versuch entsteht Kohlenstoffmonoxid. Vorsicht! Kohlenstoffmonoxid (CO) ist ein hoch giftiges Gas! Diesen Versuch nur im Freien oder im Abzug durchführen! --> Video

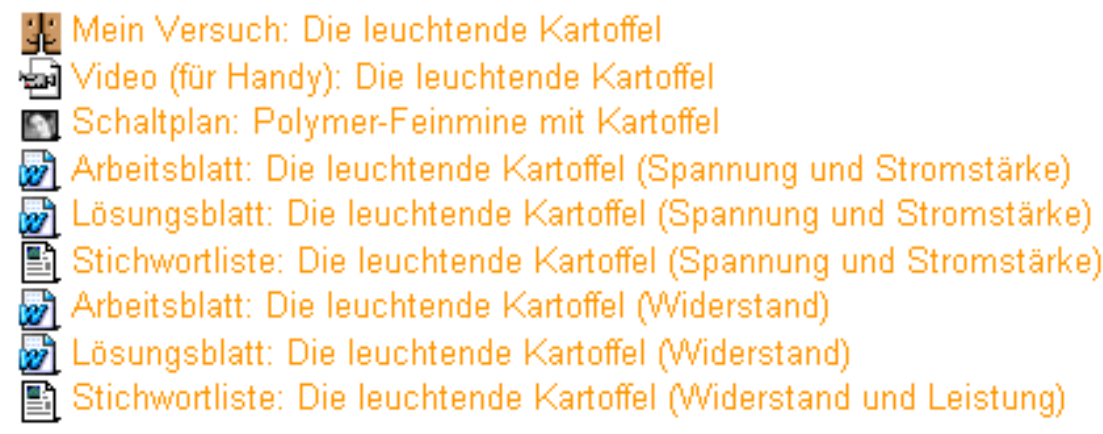

Figur 5. Unit: Spannung und Stromstärke (amperage and voltage): Die leuchtende Kartoffel (den lysende kartoffel). Schittelkopf 2007. URL: http://moodle.mobileclassroom.at/moodle18/course/view.php?id=5 


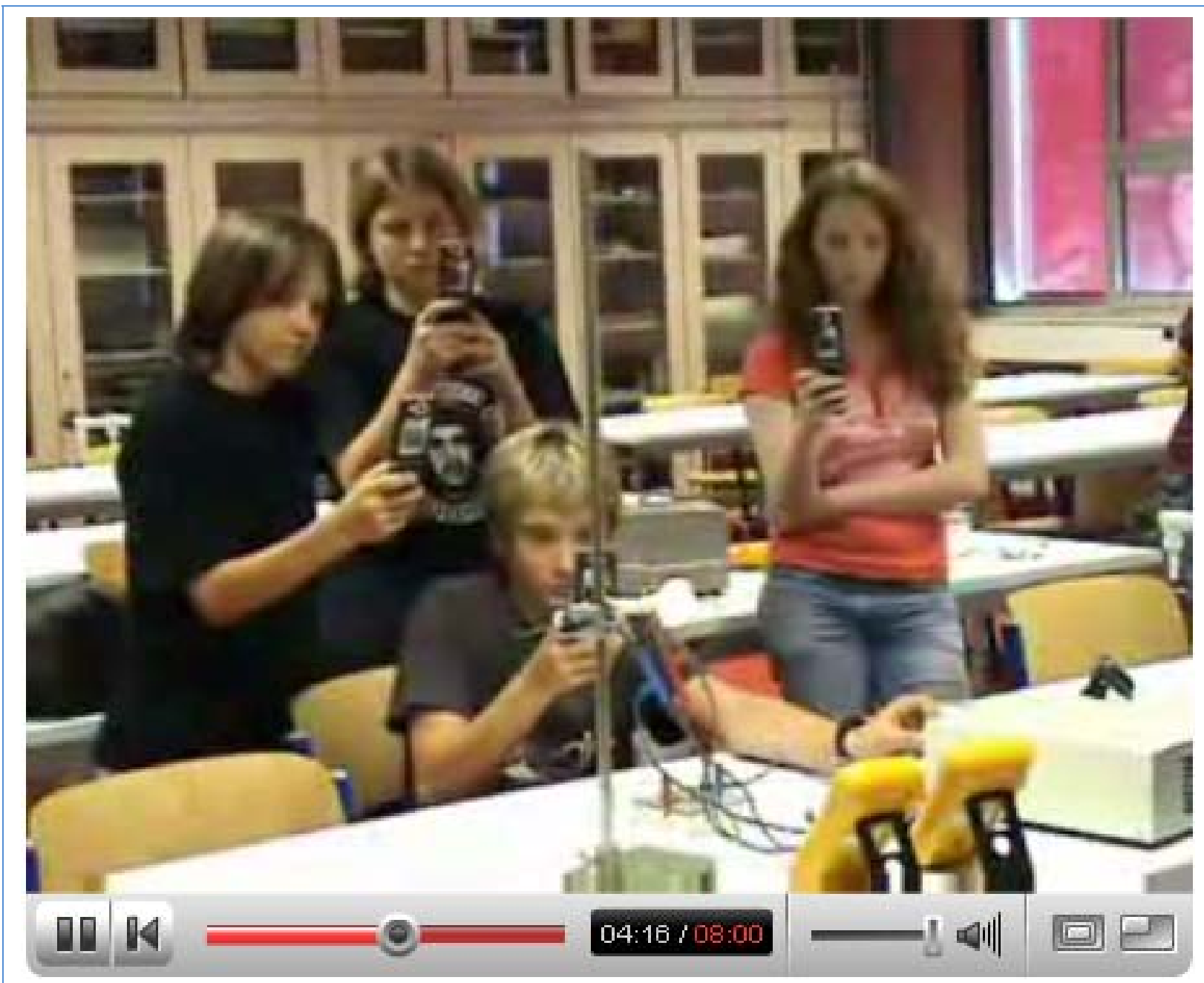

Figur 6. Unit: Spannung und Stromstärke (amperage and voltage): Elever optager et eksperiment med deres mobiltelefoner. URL: http://www.youtube.com/watch?v=zwgKnooEKlk 


\section{Re: Die leuchtende Kartoffel}

von Handy 3 N71 - Dienstag. 5 Juni 2007, 15:09

$$
\text { 몽 } 05062007016.3 \mathrm{gp}
$$

mit 3 minen

Ursprungsbeitrag | Antwort

\section{Re: Die leuchtende Kartoffel}

von Handy 3 N71 - Dienstag. 5 Juni 2007, 15:09

9mm mine mit stück kartoffel
Ursprungsbeitrag | Antwort
당

- Re: Die leuchtende Kartoffel

von Handy 11 N71 - Samstag, 9 Juni 2007, 16:51

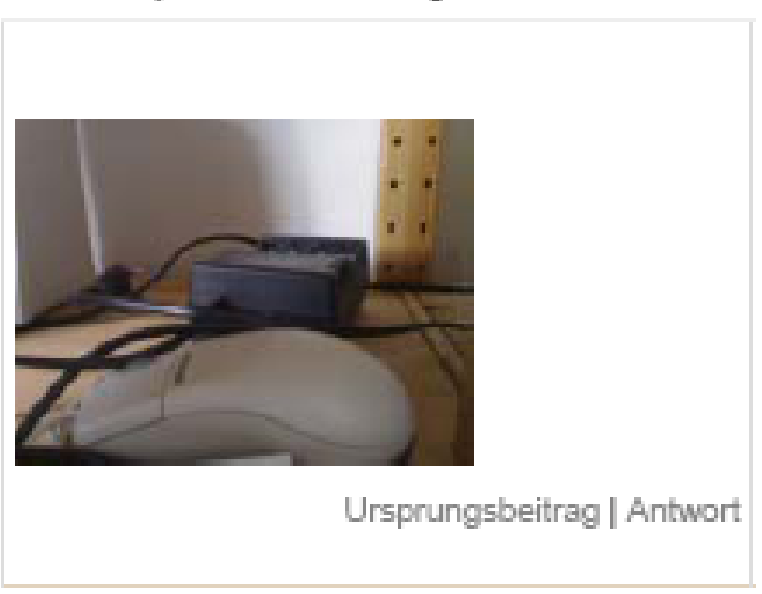

Figur 7. Spannung und Stromstärke: Elevernes offentliggørelse af deres resultater i et moodle forum. URL: http://www.mobileclassroom.at/moodle/course/view.php?id=23 
Brugen af mobiltelefoner i "momo"-projektet har med funktioner som kommunikation, produktion, distribution og arkivering at gøre: sms'er, billeder, videoer og muligheden for at uploade til en platform.

Kommunikationsfunktionen, der involverer det at sms'e, bliver i klassesammenhænge brugt til at specificere indholdet af det, der bliver uploadet (figur 7). Brugen af optagefunktioner, billeder og videoer bliver brugt til at skabe objektivt og sammenlignelig dokumentation og materiale til senere genkaldelse. Det konvergerende medie, et forum på en moddleplatform, bliver anvendt til lagring af materiale i et arkiv til senere genkaldelse. Alle medier og funktioner bliver brugt til dokumentation og lagring. Andre af mobiltelefonens funktioner samt den konvergerende medieplatform inkluderes ikke, herunder deres funktioner i hverdagen, hvilket måske først og fremmest er kommunikation og informationssøgning.

\section{"Handy"-projektetix}

"Handy"-projektet blev iværksat af en lærer i en svejtsisk privatskole med speciale i idræt. Mobiltelefonen blev brugt som et læringsredskab samt som et forskningsemne. Målet med projektet var at informere eleverne, og støtte dem i brugen af deres mobiltelefoner. Dette inkluderede ikke blot at gøre eleverne opmærksomme på deres udgifter eller andre risici, de evt. udsatte sig selv for ved at bruge mobiltelefonerx. Læreren havde også til hensigt at vise dem, hvordan mobiltelefoner kan bruges i

skolesammenhænge og dermed i læreprocessen, samt til at bringe emnet om telefonsamtalers formelle aspekter på bane (f.eks. i forbindelse med jobansøgning eller til at kommunikere i formelle miljøer) (Deubelbeiss 2007).

I den praktiske del af projektet anvendte eleverne deres egne mobiltelefoner. Der var ingen finansiel, teknisk eller infrastrukturel støtte udefra - bortset fra projektkoordinatorens engagement. Eleverne blev bedt om at arbejde på et emne i enten tysk, fransk eller matematik med henblik på at fremstille mikro-indhold ('microcontent') xi. Eleverne måtte selv vælge skolefaget samt medieformatet (film, billede, lyd eller tekst). For projektkoordinatoren var det mere vigtigt, at eleverne løste en opgave og fremstillede mikro-indhold for at holde sig til målene i læseplanen.

Ifølge projektkoordinatoren anvendte eleverne nogle af de billeder, der allerede var tilgængelige på deres telefoner, og derfor blev de ikke fremstillet eksplicit til denne øvelse (se f.eks. syntakseksemplet nedenfor). Andre billeder blev taget fra lærebogen (se f.eks. eksemplerne fra matematik og fransk nedenfor). Mikro-indhold i form af MMS (billedbeskeder) blev gemt som udkast og distribueret via Bluetooth til projektkoordinatorens mobiltelefon. Hvad angik de tekstbaserede dele 
rettede han sprog og retskrivning og uploadede de korte indlæg til en offentlig weblog for egen regning med sin mobiltelefon.

\section{Weg-Zeit-Diagramm} 3. Sek.

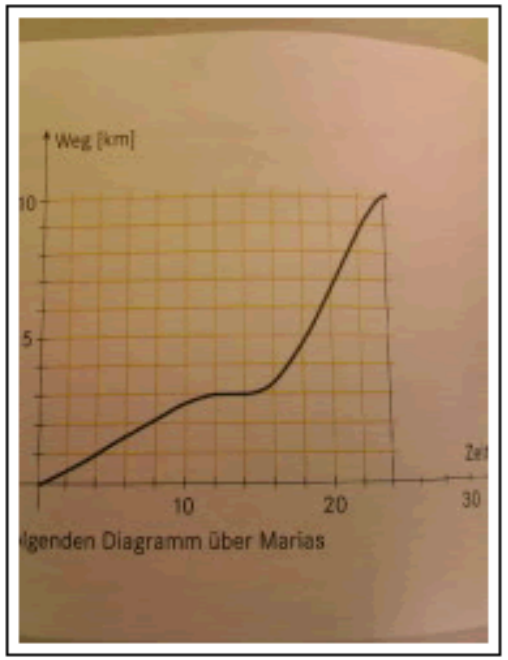

Was kannst du aus dem Diagramm über Marias Schulweg alles herauslesen? «Lösung» Der Schulweg ist $10 \mathrm{~km}$ lang und Maria benötigt dafür $24 \mathrm{~min}$ Für die erstem $3 \mathrm{~km}$ braucht Maria $12 \mathrm{~min}$, es geht wahrscheinlich bergauf, dann macht sie $2 \mathrm{~min}$ Pause, die restlichen $7 \mathrm{~km}$ legt sie in 10 min zurück. Steile Kurve bedeuted schnelle Fahrt. Flache Kurve bedeuted langsame Fahrt.

PUBLISHED IN MATHEMATIK, KOMMENTARE(0) PERMALINK

Figur 8. Matematik: Path-time-diagram (Weg-Zeit-Diagramm). URL: http://metaportfoliophsg.kaywa.ch/mathematik/index.html 


\section{$\underline{\text { Satzglieder }}$} 3. Sek.

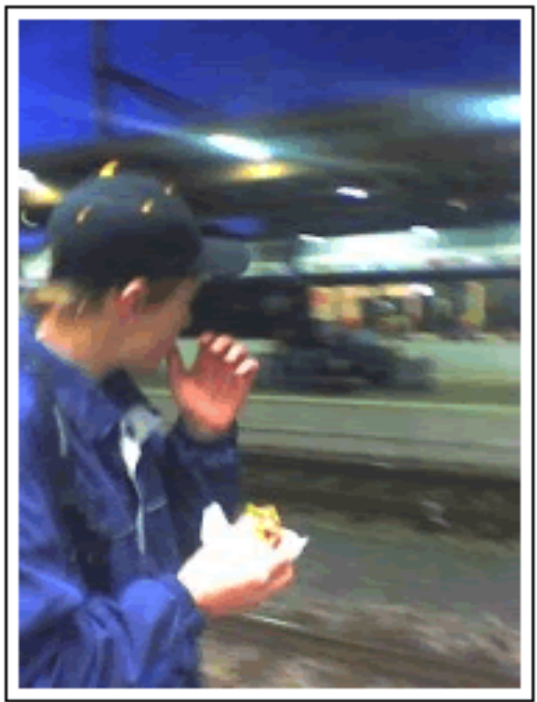

Hier mein Bild von Fabian :-) und hier einen Satz dazu, bei dem du die Satzglieder bestimme musst:

\section{Kannst du die Satzglieder bestimmen?}

1. Fabian 2.isst 3.einen Hamburger 4.am Bahnhof.

\section{Lösung:}

1. Subjekt

2. Verb

3. Objekt

4. Präpositionalobjekt

PUBLISHED IN DEUTSCH, $13.3 .2007,18: 37$

KOMMENTARE(0) PERMALINK

Figur 9. Tysk: Syntaks (Satzglieder). URL: http://metaportfoliophsg.kaywa.ch/deutsch/index.html 


\section{$\begin{array}{ll}\text { M. est plus grand que... } & \text { 2. Sek. }\end{array}$}

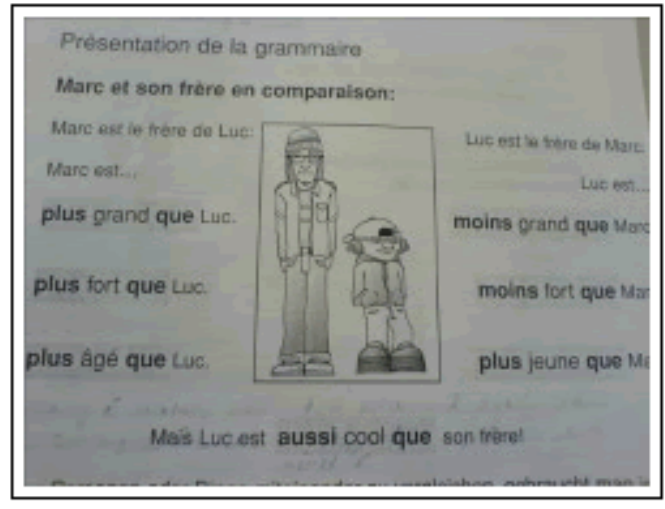

$\underline{\text { Memo.mp } 3}$

Marc est plus grand que Luc, plus fort que Luc, plus agé que Luc.

PUBLISHED IN FRANZÖSISCH, KOMMENTARE(0) PERMALINK

Figur 10. Fransk: "M. est plus grand que". URL: http://metaportfoliophsg.kaywa.ch/franzoesisch/index.html

Lydfilen "M. est plus grand que" er tilgængelig på http://metaportfoliophsg.kaywa.ch/files/2007/3/Memo.mp3

Brugen af mobiltelefoner - også inden for "Handy"-projektet - omhandler funktioner som kommunikation, produktion, distribution og arkivering: sms'er, billeder, videoer og muligheden for at uploade til en platform. Kommunikationsfunktionen, der involverer sms'er, bliver brugt til at producere tekst som en integreret del af en multimodal opgave ("Syntaks") og til at skrive overskrifter ("M. est plus grand que"). Optagefunktionerne såsom billeder og lyd bliver også anvendt enten som en integreret del af en opgave ("Path-Time diagram"), til at tilvejebringe ekstra information ("M. est plus grand que") eller som reference til opgavens originale kontekst ("Syntaks"). Det konvergerende medie, internettet, bliver anvendt ved hjælp af en offentlig weblog, således at arkiveringsfunktionen bliver fremhævet ved at bruge webloggen til lagring af læringsressourcer.

I forhold til brugen af tekst står vejledning og information centralt. Kommunikation som en diskursiv og forhandlende aktivitet synes ikke at være et centralt emne. 
Projektet: "How mobile phones help learning in the secondary school" (Hvordan mobiltelefoner bidrager til læring $i$ ungdomsuddannelserne)

Projektet "How mobile phones help learning in the secondary school" blev iværksat af the Learning Sciences Research Institute på University of Nottingham. Projektet havde til hensigt at anbefale "the need to shift the focus of policy away from the devices themselves to consider the frequently-reported reasons that mobile phones are banned: fear of distraction in class, cheating, inappropriate recording of students and teachers, and publication on sites like YouTube. Solutions must be found to each of these, in policies that address:

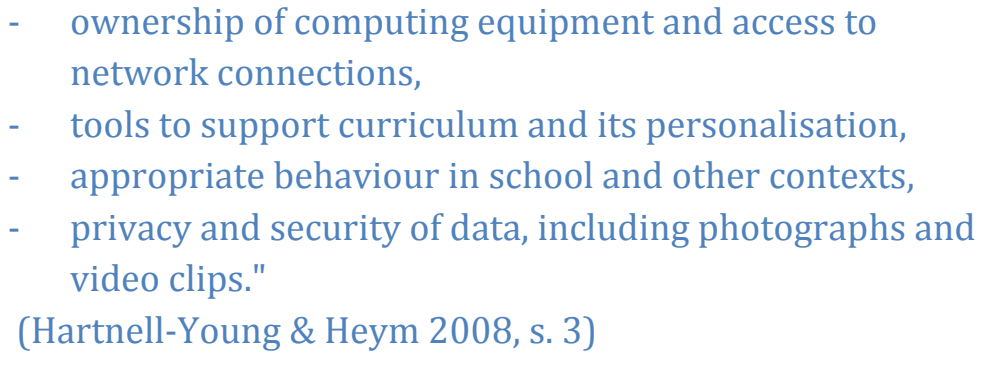

311 elever (9-11-årige) fra 3 forskellige skoler og uddannelsestrin deltog i dette projekt i $2006 \mathrm{og} /$ eller 2007. Eleverne i skole A benyttede deres egne mobiltelefoner, eleverne i skole $\mathrm{B}$ benyttede deres egne SIM-kort i ulåste smart phones, der blev stillet til rådighed, og i C-gruppen fik eleverne udlånt ulåste smart phones og SIM-kort, som kun var tilgængelige for grupper med 2 personer og kun i mindre end en dag.

Brugen af mobiltelefoner omfattede forskellige fag og adskillelige funktioner på mobiltelefonerne - antageligt allerede før projektet begyndte. Selvom projektet indbefatter forskellige indfaldsvinkler til mobil læring, en bred vifte af funktioner på mobilerne samt en lang række af elevaktiviteter, synes aspektet omkring den pragmatiske brug at være centralt for de lærere, som er involveret i dette projekt (f.eks. at bruge lommeregnere i matematik eller fysik, tage billeder for at sikre "videnskabelig gyldighed", download af podcasts for at forbedre sprogfærdigheder i fremmedsprog, sende sms'er med påmindelser om hjemmearbejde, gå på internettet for at samle information osv.). 


\begin{tabular}{|l|l|}
\hline Matematik & $\begin{array}{l}27 \\
\%\end{array}$ \\
\hline $\begin{array}{l}\text { Naturviden } \\
\text { skab }\end{array}$ & $\begin{array}{l}15 \\
\%\end{array}$ \\
\hline Engelsk & $\begin{array}{l}11 \\
\%\end{array}$ \\
\hline Geografi & $\begin{array}{l}11 \\
\%\end{array}$ \\
\hline Ikt & 9 \\
& $\%$ \\
\hline
\end{tabular}

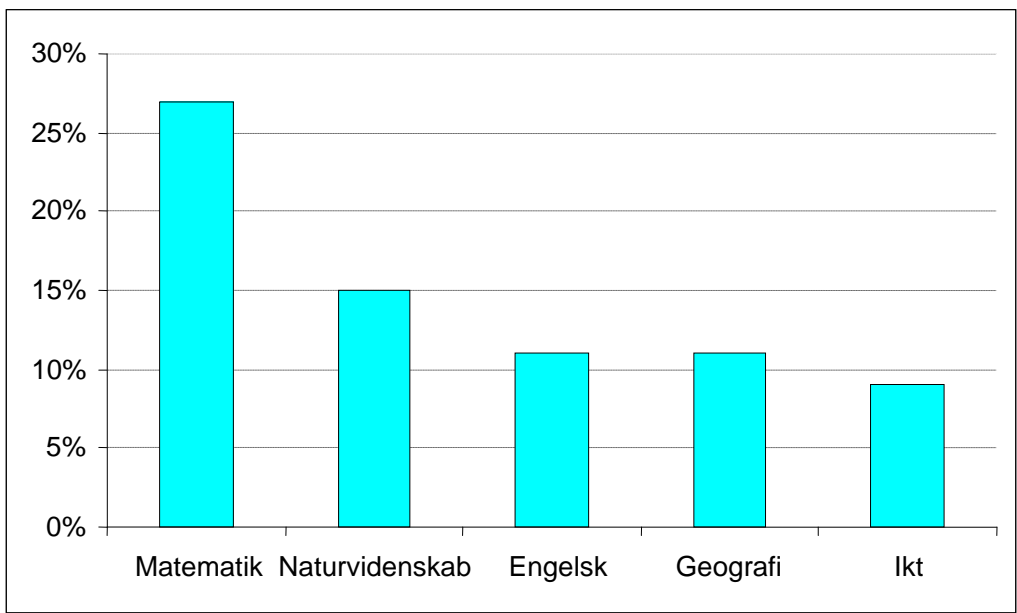

$n=331$

Figur 11. Grundlæggende brug i skolefag på tværs af skoler. Hartnell-Young \& Heym 2008, s. 7. URL: http://schools.becta.org.uk/uploaddir/downloads/page documents/research/lsri report.pdf

\begin{tabular}{|l|l|}
\hline Lommeregner & $37 \%$ \\
\hline SMS & $19 \%$ \\
\hline Kamera & $18 \%$ \\
\hline Stopur & $16 \%$ \\
\hline MP3 & $14 \%$ \\
\hline WWW & $11 \%$ \\
\hline Telefonopkald & $9 \%$ \\
\hline
\end{tabular}

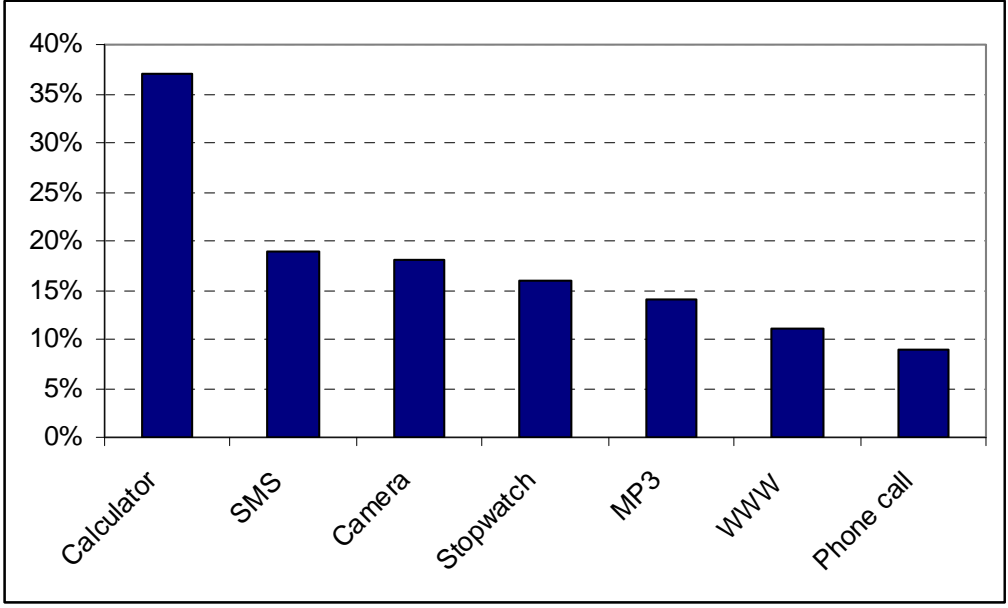

$n=331$

Figur 12. Reporteret brug af telefonfunktioner i løbet af timerne. Hartnell-Young \& Heym 2008, s. 8. URL: http://schools.becta.org.uk/upload-

dir/downloads/page documents/research/lsri report.pdf 
Brugen af mobiltelefoner i "How mobile phones help learning in secondary school"-projektet omhandler funktioner som kommunikation, produktion, distribution og arkivering - og er derfor på linje med de to andre projekter "momo" og "Handy": sms'er, billeder, videoer og muligheder for at uploade til et konvergerende medie, en platform. Men sammenlignet med de to andre projekter er der her tale om en bred vifte af funktioner i en situeret og formodet "passende" brug i bestemte kontekster. Sms'er bliver ofte anvendt til at sende påmindelser til elever og til at kommunikere med læreren. Billeder, videoer og lyd bliver brugt til at optage eksperimenter til videnskabelig gyldighed og til at lagre dem til senere brug. Billeder (images) anvendes til støtte for skriftlige redegørelser eller kommentarer eller fungerer som visuelle noter. Endvidere anvendes den mobile enhed til distribution og lagring af læringsressourcer, til at flytte filer med henblik på udskrift, til at opbevare og/eller downloade hjemmearbejde til mobiltelefonen, eller til at uploade ideer, opgaver eller dokumentation af eksperimenter til en hjemmeside. Som endnu et konvergerende medie blev pc'en anvendt til infrastrukturel organisering ved at producere tidsplaner, der anvendte alarmfunktionen på mobiltelefonen kombineret med 'to do'listen. Selvom mulighederne for dokumentation og lagring også her dækker et bestemt område, er kommunikation og organisering bemærkelsesværdige elementer, som bevæger sig ind i yderligere læringsdimensioner i form af en diskursiv og kommunikativ læringsmodel (se også Laurillard 2002, 2007), samt aspektet om organisering og infrastruktur, som grundlæggende forudsætninger for en selvstyret læring.

\section{Mobil læring i skoler indbefatter den regulerede brug af mobiltelefoner og lærernes tøvende accept af elevernes kulturelle praksisser og situerede muligheder}

Mobiltelefoner bliver brugt som emner og som redskaber inden for læring, og apparaternes funktioner er normalt ikke begrænset til anvendelse af én funktion udelukkende. Tekst, billede, video og lydoptagelsesfunktionerne foretrækkes. Men selvom kontinuerlig læring står i forbindelse med ressourcer såsom tid, sted, rum og indhold, mangler der ofte sammenhæng, når det kommer til elevernes kulturelle praksisser. Der synes også at være en mangel i integrationen af nogle af de mest originale muligheder, der karakteriserer mobil læring: samarbejdsmæssig, konverserende og situeret meningsdannelse. For at tilpasse dem til læring i skolesammenhænge og for at understøtte elevernes meningsdannende proces, er det måske værd at betragte elevernes oplevelser af regler og forskrifter og deres evner til at 
indpasse og videreudvikle sådanne regler og forskrifter afhængigt af situationen og i socialt samspil - også i forbindelse med brugen af hverdagens teknologi, mobiltelefonen, i skolesammenhænge.

\section{Mellem styret brug og åbne, konstruktivistiske omgivelser}

Mobil læring vender i disse tre eksempler tilbage til mobiltelefoner som apparater, og også de anvendte funktioner og applikationer ligner hinanden. De bliver anvendt med henblik på læseplanen og en bestemt opgave, der bliver defineret af læreren i forvejen. De henviser ofte til et lager i form af en platform eller en weblog til at lagre materialer og have det tilgængeligt til senere brug. Men hensyn til aktiviteterne, som blev implementeret enten i lærerens undervisning eller situationen, blev eleverne enten styret (som i "momo"-eksemplet), eller også var de forholdsvis frie til at vælge, hvordan de ville bruge mobiltelefonerne (som i projektet af Hartnell-Young). Man kunne også forsigtigt antage, at det didaktiske design omfatter behavioristisk læring på den ene side og åben uddannelse med elementer af eksperimentel og legende læring på den anden. Mere generelt kan man nå frem til, at mobiltelefoner anses enten som redskaber i et ret begrænset omfang, der fokuserer på transmission af information, eller at de på den anden side fokuserer på elevernes handlen og kulturelle praksisser samt på situeret læring og dens muligheder.

\section{Re-kontekstualisering og situeret forhandling: forudbestemt brug eller frit rum?}

Et kig på funktionaliteten (dvs. de muligheder, der kommer til syne, når man bruger en bestemt funktion) i de tre eksempler kan måske give en forklaring på det "skel", der eksisterer mellem de to kontekster - skolen og hverdagen: Mobiltelefonen har tilbøjelighed til at være et kommunikationsmiddel, når det kommer til kommunikation i unge menneskers hverdag, hvorimod den bliver sat ind i en ny sammenhæng og dermed f.eks. bliver et dokumentationsredskab i skolen. Man kan påpege, at sådan et skift måske kan forhandles i brug (vha. Bakardjevas og Cook et al.s idéer om elevgenerede kontekster). Men man kan også henvise til London Knowledge Labs forskningsresultater, som hævder at skolens samling af regler og forskrifter til skolelæring, måske får børnene til at handle, uden at de tillader sig selv at referere til de aspekter af mobiltelefoner, der har med sjov og kommunikation at gøre. Kommunikation anvendes faktisk ikke så ofte i m-læring, som man kunne have forestillet sig, eftersom telefon- og tekstfunktionerne er de mest anvendte funktioner uden for skolen. Udelukkelsen af denne typiske hverdagsmæssige brug af mobiltelefoner markerer ikke blot et skel mellem henholdsvis hverdagslivet og skolen - en opfattelse af "at være afkoblet". Den peger også på det faktum at kommunikative og diskursive praksisser i processen for meningsdannelse, som er baseret på kommunikation, ikke er 
hovedspørgsmålet i alle projekter med m-læring.

At indfange situationer eller generere kontekster? Fra ad hoc til hæmmet brug

At dømme efter fravælgelsen af kommunikation til fordel for dokumentation bliver konvergerende medier såsom platforme og weblogs anvendt som lagre eller arkiver. Deres relevans i forhold til informationssøgning - som er en af de aktiviteter, unge mennesker oftest engagerer sig i uden for skolen - er ikke den dominerende funktion i skolen. I stedet opbevarer de dokumenter, som blev fremstillet med mobiltelefonen f.eks. billeder, film eller lydoptagelser osv. med henblik på pålidelighed, bæredygtighed og senere brug. I lyset af den tendentiøse udeladelse af kommunikation og informationssøgning kan man antage at den meningsdannende proces, opbygningen af fælles og forhandlet mening og viden, bliver "outsourcet" til et andet mediexii. Som en konsekvens kunne man påstå, at de umiddelbare, "ad hoc"-idéer om mobiltelefoner er hæmmet, samt at mobiltelefoner fungerer som redskaber til at indfange øjeblikkelighed eller situationer snarere end at sætte eleverne i stand til øjeblikkeligt at få adgang til eller udvikle situationer og kontekster.

Sådanne specifikke anvendelser - ad hoc eller på et senere tidspunkt i læreprocessen - var måske i lærerens hensigt, da denne også bestemmer det didaktiske design (f.eks. med fokus på indhold, kontekst eller muligheder). Eller også bliver de måske ikke anvendt af eleverne, fordi de forsøger at holde sig til skolens krav i forbindelse med regler og forskrifter. Men en mulighed er, at alle elever vil have adgang til læringsressourcer på en platform og derfor ikke er afhængige af en situeret succes eller fiasko i deres aktuelle opgave.

\section{Regler som konstruerede platforme kan tilvejebringe rum til forhandlende og handlende meningsdannelse for elever}

Ved at referere til regler som strukturer, der forbinder hverdags- og skolekontekster, bliver fokus lagt på den dynamiske dimension i brugen af mobiltelefoner i skoler - hvilket gør relevansen af spørgsmålet om et potentielt skift fra ad hoc til et senere stadie relativt. Den bagvedliggende formodning er, at regler enten er bestemt i forvejen, er stabile og forudsigelige, eller at de er dynamisk forhandlede og ændres i forhold til en bestemt mulighed. Som de tre eksempler sigter efter at vise, realiseres både en reguleret og foruddefineret brug af mobiltelefoner i projekter om m-læring såvel som en åben brug, der er baseret på situerede forhandlinger og brugen af telefonen i forhold til dens situerede muligheder. Dette sidstnævnte didaktiske design er det, der synes at være mest åbent for en dynamisk brug af mobiletelefoner af eleverne, og som tillader eleverne at henvise til deres handlen og meningsfulde brug af redskabet afhængig af situationen og af den formodede mulighed. Senere er eksemplerne måske i stand til at vise, at måden, hvorpå mobiltelefoner bliver anvendt i skolerne, 
ofte er forudbestemt af læreren, som er ansvarlig for sine klassers didaktiske design. Derfor er en "åben" og dynamisk brug ikke altid en mulighed - eller endda en nødvendighed. Imidlertid bliver regler betragtet som konstruktioner, der understøtter fælles læringsbaggrunde og meningsdannelser, som også kan ske afhængigt af situationen eller spontant. Måske er almindeligt forhandlede regler strukturer, der kan forbinde skolen med elevernes livsverdener. De indeholder deres udvikleres forskellige meninger, oplevelser, intentioner osv. og står i forbindelse med elevernes kulturelle praksisser samt med deres situerede og formodede muligheder. Derfor er didaktiske designs, som tilbyder rum, hvori lærerne og eleverne kan forhandle regler for f.eks. brugen af mobiltelefoner, ikke blot diskursive måder, hvorpå man kan nærme sig fælles betydninger eller udvikle elevens viden, men også måder til at acceptere og integrere subjektive betydninger og kulturelle praksisser med objektive og almindelige af slagsen.

\section{Hjemmesider}

Alfred-Teves-Schule (2008): Schulwebseiten der Grund- und Hauptschule Alfred-Teves-Schule, Gifhorn. Gewaltprävention - Die Medien AG der Alfred-Teves-Schule. Online: http://www.alfred-tevesschule.de/schulwebseiten/de/Medien-AG/index.php, (Accessed: 31 August 2008).

Becta: Becta. Leading next generation learning. Online: http://www.becta.org.uk, (Accessed: 10 August 2008).

Bullying Online (2008): Bullying UK - Help us to support the UK's children. Online: http://bullying.co.uk/, (Accessed: 28 August 2008).

Deubelbeiss, Rolf (2007): Beispiel-Sammlung Projekt "Handy". Online: http://metaportfolio-phsg.kaywa.ch, (Accessed: 10 August 2008).

Deubelbeiss, Rolf (2008): http://klippundklar.blog.de. Online: http://klippundklar.blog.de/, (Accessed: 31 August 2008).

ecmc GmbH innerhalb des Konsortiums klicksafe.de: klicksafe.de. Mehr Sicherheit im Internet durch Medienkompetenz. Online: http://www.klicksafe.de, (Accessed: 10 August 2008).

Finck, Norbert (2001): Mathematik-8: Projekt "Handy". Lernsituation / Projekt "Gebühren und Tarife". Online: http://members.aol.com/nfinckx/m8handy/m8handy.htm, (Accessed: 10 August 2008).

Futurelab: Futurelab. Innovation in education. Online: http://www.futurelab.org.uk, (Accessed: 10 August 2008). 
International Association for Mobile Learning (IAMLearn): IAML - Mobile Learning. Online: http://mlearning.noe-kaleidoscope.org, (Accessed: 10 August 2008).

Internet-ABC e.V.: Internet-ABC - Startseite. Online: http://internetabc.ch/kinder, (Accessed: 10 August 2008).

Kanton Zürich (2004): Gewalt und Pornografie auf dem Handy (E-Lesson). Kantonspolizei - Sicherheitsdirektion - Internet Kanton Zürich. Online: http://www.kapo.zh.ch/internet/ds/kapo/de/aktuell/E_Lesson.html, (Accessed: 10 August 2008).

Landesanstalt für Medien Nordrhein-Westfalen (LfM); Medienpädagogischer Forschungsverbund Südwest (mpfs): handysektor. Online: http://www.handysektor.de/, (Accessed: 10 August 2008).

London M-Learning Group (2008): London M-Learning Network. Hosted by the WLE - Centre for Excellence. Online: http://www.londonmlearning.net, (Accessed: 10 August 2008).

lo-net GmbH: Lehrer-Online. Online: http://www.lehrer-online.de, (Accessed: 11 August 2008).

Mobile Industry Crime Action Forum (2008): Out of Your Hands? Online: http://www.outofyourhands.com/, (Accessed: 28 August 2008).

Österreichisches Institut für angewandte Telekommunikation (ÖIAT): Handywissen.at. Das Handy sicher und kostengünstig nutzen. Online: http://www.handywissen.at/, (Accessed: 10 August 2008).

PhonepayPlus (2008): PHONEbrain. Online: http://www.phonebrain.org.uk/, (Accessed: 28 August 2008).

Schittelkopf, Eduard (2007): Kurs: Spannung und Stromstärke. Online: http://moodle.mobileclassroom.at/moodle18/course/view.php?id=5, (Accessed: 31 August 2008); <http://www.mobileclassroom.at/moodle/course/view.php?id=23> (Accessed: 24 August 2007).

Schweizer Fernsehen (SF) (2003): Dossier Handy. SF Wissen mySchool, SF 1. Online: http://www.sf.tv/sf1/myschool/detailinfo.php?docid=3193, (Accessed: 10 August 2008).

Vadas, N.; Ellenberger, J.; Hollenstein, S. (2007): Dossier Handy. Webquest zum Film "Dossier Handy". Online: http://edavs.educanet2.ch/handy/.ws_gen/, (Accessed: 10 August 2008). 


\section{Litteratur}

Arnedillo-Sánchez, Inmaculada (2008): The mobile digital narrative tool. IADIS International Conference Mobile Learning 2008.

Bachmair, Ben (2004): Projekt www.Schulmedientauschbörse.de. Online: http://www.medienpaed-kassel.de/index.php?page=ForschungSchulmedientauschboerse, (Accessed: 31 August 2008).

Bachmair, Ben (2008): Topography of an ecological approach to m-learning in the context of global cultural transformation. Draft. Unpublished. 3 September 2008.

Bakardjieva, Maria (2005): Internet society. The internet in everyday life. London: SAGE Publications.

Bauer Media KG (Ed.) (2004): BRAVO Faktor Jugend 7: Marken und Trends. Online: http://www.bauermedia.com/fileadmin/user_upload/pdf/studien/ziel gruppe/jugend/jugend7.pdf, (Accessed: 10 August 2008).

Bauer Media KG (Ed.) (2005): BRAVO Faktor Jugend 8: Now and Forever Jugendliche Markenbeziehungen in der Retrospektive. Online: http://www.bauermedia.com/fileadmin/user_upload/pdf/studien/ziel gruppe/jugend/jugend8.pdf, (Accessed: 10 August 2008).

Bauer Media KG (Ed.) (2007): BRAVO Faktor Jugend 9: Jugend \& Medienfreunde. Online: http://www.bauermedia.com/fileadmin/user_upload/pdf/studien/ziel gruppe/jugend/Bravo_Faktor_Jugend_Brosch_re.pdf, (Accessed: 10 August 2008).

Brynskov, Martin (2007): Tools for social construction: A framework for pervasive media for children. PhD dissertation. Aarhus. University of Aarhus, Faculty of Science.

COMM/EAC (2008): EUROPA - Education and Training - Lifelong Learning. Online: http://ec.europa.eu/education/policies/lll/life/what_islll_en.html, (Accessed: 21 December 2008).

Cook, John; Bradley, Claire; Lance, Justin; Smith, Carl; Haynes, Richard (2007): Generating learning contexts with mobile devices. In: Pachler, Norbert (Ed.): Mobile learning - towards a research agenda. London: WLE Centre (Occasional Papers in Work-based Learning), s. 55-74.

Cranmer, Sue; Potter, John; Selwyn, Neil (2008): Learners and technology: 7-11. Edited by Becta. (Becta research reports). Online: http://partners.becta.org.uk/index.php?section=rh\&catcode=_re_rp_02 \&rid=14837, (Accessed: 31 August 2008).

Deubelbeiss, Rolf (2007): Das Handy an der NET. Verbote, Gebote, Lifestyle, Jugendkultur, Lernhilfe ... ? Begleitbrief an Eltern. Nationale 
Elitesportschule Thurgau. Online: http://metaportfoliophsg.kaywa.ch/files/Das\%20Handy\%20an\%20der\%20NET\%20Begleit brief.pdf, (Accessed: 10 August 2008).

Div.; Wikipedia (2008): Learner generated context. Online: http://en.wikipedia.org/wiki/Learner_generated_context, (Accessed: 15 September 2008).

Dourish, Paul (2004): What we talk about when we talk about context. In: Personal and Ubiquitous Computing, Vol. 8, Issue 1, s. 19-30. Online: http://www.ics.uci.edu/ jpd/publications/2004/PUC2004-context.pdf, (Accessed: 10 August 2008).

Featherstone, Mike (2006): Archive. In: Theory Culture and Society, Vol. 23, Issue 2, s. 591-597.

Futurelab (2008): Enquiring Minds. Online: http://enquiringminds.org.uk/, (Accessed: 19 August 2008).

Glotz, Peter; Bertschi, Stefan; Locke, Chris (2005): Thumb Culture: The Meaning Of Mobile Phones For Society. Bielefeld: Transcript.

Hartnell-Young, Elizabeth; Heym, Nadja (2008): How mobile phones help learning in secondary schools. A report to Becta. Copyright University of Nottingham. Online: http://schools.becta.org.uk/uploaddir/downloads/page_documents/research/lsri_report.pdf, (Accessed: 31 August 2008).

Hug, Theo (Ed.) (2007): Didactics of Microlearning. Concepts, Discourses and Examples. Münster/ New York/ Berlin/ München: Waxmann.

Kress, Gunther; Leeuwen, Theo van $(1996,2006)$ : Reading Images: The grammar of visual design. London: Routledge.

Kukulska-Hulme, Agnes (2005): Introduction. In: Kukulska-Hulme, Agnes; Traxler, John (Eds.): Mobile Learning. A Handbook for Educators and Trainers. New Edition. London, New York: Routledge (The Open and Flexible Learning Series), s. 1-6.

Kukulska-Hulme, Agnes; Traxler, John (Eds.) (2005): Mobile Learning. A Handbook for Educators and Trainers. New Edition. London, New York: Routledge (The Open and Flexible Learning Series).

Laurillard, Diana (2002): Rethinking university teaching. A conversational framework for the effective use of learning technologies. 2. Edition. London: RoutledgeFalmer.

Laurillard, Diana (2007): Pedagogical forms for mobile learning: framing research question. In: Pachler, Norbert (Ed.): Mobile learning - towards a research agenda. London: WLE Centre (Occasional Papers in Workbased Learning), s. 153-175.

Ling, Richard (2008): New Tech, New Ties: How Mobile Communication Is Reshaping Social Cohesion?: MIT Press. 
London M-Learning Group (2008): London M-Learning Network. Hosted by the WLE - Centre for Excellence. Online: http://www.londonmlearning.net, (Accessed: 10 August 2008).

Luckin, Rosemary; Du Boulay, Benedict; Smith, Hilary; Underwood, Joshua; Fitzpatrick, Geraldine; Holmberg, Joseph et al. (2005): Using Mobile Technology to Create Flexible Learning Contexts. In: Journal of Interactive Media in Education, Issue 22. Online: http://jime.open.ac.uk/2005/22/luckin-2005-22.pdf, (Accessed: 10 August 2008).

Medienpädagogischer Forschungsverbund Südwest (mpfs) (Ed.) (2008): JIM 2008. Jugend, Information, (Multi-)Media. Basisstudie zum Medienumgang 12- bis 19-Jähriger. Online: http://mpfs.de/fileadmin/JIM-pdf08/JIM-Studie_2008.pdf, (Accessed: 21 December 2008).

Naismith, Laura; Lonsdale, Peter; Vavoula, Giasemi; Sharples, Mike (2004): Literature Review in Mobile Technologies and Learning: Report 11. Bristol: Futurelab.

Pachler, Norbert (2008): Mobiles Lernen: Spleen oder Paradigmenwechsel? In: E-Learning Dossier, Issue 3. Mobile Learning - eine neue Erfolgsstory. Online: http://www.elearning.zfh.ch/upload/Artikel_Pachler.pdf, (Accessed: 10 August 2008).

Rummler, Klaus (2005): Realitätsnähe von Kinderfernsehprogrammen und geschlechterspezifische Fernsehnutzungspräferenzen. Magisterarbeit. Betreut von Ben Bachmair. Kassel. Universität Kassel. Online: http://kobra.bibliothek.uni-kassel.de/handle/urn:nbn:de:hebis:342007111519619, (Accessed: 31 August 2008).

Schittelkopf, Eduard (2007): MobileClassRoom (MCR) - mobile online Learning (mLearning). Interview with Prof. Eduard Schittelkopf. Edited by nischiTV. Online: http://www.youtube.com/watch?v=zwgKnooEKlk, (Accessed: 31 August 2008).

Schweizer, Herbert (2007): Soziologie der Kindheit. Verletzlicher EigenSinn. Wiesbaden: VS Verlag für Sozialwissenschaften.

Seipold, Judith (2005): Beobachtungen zur Dokugruppe „die rasenden Reporter“. In: Textor, Frauke (Ed.): Schulmedientauschbörse - ein Projekt zur Nutzung des Internets in der Grundschule. Wissenschaftliche Hausarbeit zur Ersten Staatsprüfung für das Lehramt an Grundschulen.

Seipold, Judith (2005): Fördert Fernsehen Medienkompetenz? Eine empirische Fernsehprogrammanalyse zum Angebot an Sendungen zur Medien- und Genrekompetenz. Supervised by Ben Bachmair. Kassel. Universität Kassel, Medienpädagogik Uni Kassel. Online: http://kobra.bibliothek.uni-kassel.de/handle/urn:nbn:de:hebis:342007111419602, (Accessed: 31 August 2008). 
Seipold, Judith (2008): Mobile phones in school. Selected m-learning projects from Great Britain and the German speaking countries. In: Hug, Theo (Ed.): Media, Knowledge \& Education. Exploring new Spaces, Relations and Dynamics in Digital Media Ecologies. Innsbruck: Innsbruck University Press - iup .

Shao, Yinjuan; Crook, Charles; Koleva, Boriana (2007): Designing a Mobile Group Blog to Support Cultural Learning. In: Norman, Austin; Pearce, Jon (Eds.): Conference Proceedings. Long and Short Papers. mlearn 2007. 6th Annual International Conference on Mobile Learning. 16-19 October 2007. Melbourne: University of Melbourne .

Sharples, Mike; Milrad, Marcelo; Arnedillo-Sánchez, Inmaculada; Vavoula, Giasemi (2007): Mobile Learning: Small devices, Big Issues: Technology Enhanced Learning: Principles and Products .

Stald, Gitte (2007): Mobile identity: youth, identity, and mobile communication media. In: Buckingham, David (Ed.): Youth, Identity, and Digital Media. Cambridge, MA: MIT Press .

The Learner Generated Contexts Group (hosted by The London Knowledge Lab): Learner Generated Contexts. Online:

http://learnergeneratedcontexts.pbwiki.com/, (Accessed: 15 September 2008).

Traxler, John (2007): Defining, Discussing and Evaluating Mobile Learning: The moving finger writes and having writ... In: The International Review of Research in Open and Distance Learning, Vol. 8, Issue 2. Online: http://www.irrodl.org/index.php/irrodl/article/view/346/882, (Accessed: 03 September 2008).

Walker, Kevin (2006): Mapping the Landscape of Mobile Learning. In: Sharples, Mike (Ed.): Big issues in mobile learning.

\section{Noter}

i Bachmairs, Pachlers, Cooks, Rummlers og Seipolds forskning er knyttet til London Mobile Learning Groups igangværende bogprojekt. De er desuden medlemmer af (LMLG) (www.londonmobilelearning.net). "The group is working on a theoretical and conceptual framework for mobile learning around the notion of cultural ecology. The analytical engagement with mobile learning of the group takes the shape of a conceptual model in which educational uses of mobile technologies are viewed in ecological terms as part of a cultural and pedagogical context in transformation" (London Mobile Learning Group 2008).

ii Tilsvarende fremgangsmåder med fokus på elevernes hverdag (hverdagslæring) og muligheder for at integrere deres kulturelle praksisser og kulturelle ressourcer i skolen ved hjælp af deres handlen gennemføres af blandt andet Futurelabs projekt Enquiring Minds 
(www.enquiringminds.org.uk) eller af projektet www.Schulmedientauschboerse.de (gennemført af Kassel Universitets Media Education Unit. Bachmair 2004; Seipold 2005a, b, 2008; Rummler 2005). Se også f.eks. Cranmer et al. 2008; Brynskov 2007.

iii Se også The Learner Generated Contexts Group 2008, og Div. \& Wikipedia 2008 for moderne definitioner af kontekst.

iv Figurerne med data om brug stammer fra Tyskland og dækker gruppen af 12-19-årige.

v I øvrigt: Det kan måske være nyttigt at betragte den slags data om brug i tilfælde af, at der mangler infrastrukturel støtte til at iværksætte projekter om m-læring i skolerne, hvilket betyder at læreren må regne med, at der ikke er udgifter og derfor må vende tilbage til allerede tilgængelige ressourcer: det faktum, at markedsandelen af mobiltelefoner spænder fra $92 \%$ til $95 \%$ for de 12-19-årige (MPFS 2007) lægger op til brugen af elevernes egne mobiltelefoner i skolerne; jo ældre eleverne bliver, jo færre apparater behøver læreren at skaffe. Det faktum, at kun fă forskellige mærker foretrækkes af de unge mellem 12 og 19 år, burde opmuntre lærere, som ikke tør have for stor variation mellem elevernes egne mobiltelefoner i projekter i skolen - hvilket kan være en hindring på det teknologiske niveau, hovedsageligt i forhold til at opnå sammenlignelighed blandt de anvendte medier.

vi Her bliver udtrykket 'didaktisk' ikke brugt i dets engelske betydning, der henviser til noget ekstremt belærende og lærercentreret, men i dets tyske (og danske) betydning som refererer til teoretiske og praktiske overvejelser med hensyn til undervisning og læring.

vii Schittelkopf 2007.

viii Dette projekt er teknologisk set baseret på "Mobile Learning Lösungen" MLE („Mobile Leaning Engine“) og moodle integration solution momo ("mobil Moodle"). Begge løsninger, MLE og momo er tilgængelige som åbne kilder (open sources) på http://sourceforge.net/projects/mobilemoodle/. 31. August 2008.

ix Deubelbeiss 2007.

x Til den teoretiske del anvendte læreren "Dossier Handy" fra Swiss Television (Schweizer Fernsehen 2003), hjemmesiden fra en kanton i Zurich (Kanton Zürich 2004) og en webquest fra (Vadas \& Ellenberger 2007).

xi Mikrolæring kan beskrives som en minimalisering, fragmentering og "element-opbygning" af læringsressourcer samt kortsigtede læringsaktiviteter. Læring finder her sted igennem elevens samling af modulopbyggede læringsenheder (se f.eks. Hug, 2007).

xii For at finde videns- og meningsdannelse ved brug af weblogs se f.eks. Shao et al. 2007, for arkiver f.eks. Featherstone 2006. 